\title{
THE MODERATING EFFECT OF HOLDING SHAREHOLDERS ON CORPORATE PERFORMANCE IN INSTITUTE SPIN-OFFS FROM THE PERSPECTIVE OF INSTITUTIONAL LOGICS
}

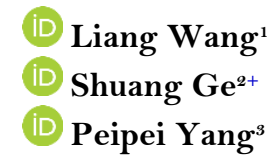

\author{
${ }^{1,2}$ School of Economics and Management, University of Chinese Academy of \\ Sciences, Beijing, China. \\ 'Email: wangliang@dicp.ac.cn Tel: 86+15998552031 \\ ${ }^{2}$ Email: geshuang17@mails.ucas.ac.cn Tel: 86+13269339680 \\ ${ }^{3}$ Sino-Danish College, University of Chinese Academy of Sciences; Sino- \\ Danish Center for Education and Research, Beijing, China. \\ ${ }^{3}$ Email:yangpeipei18@mails.ucas.ac.cn Tel: 86+18810356055
}

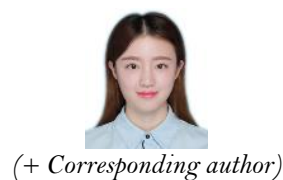

(+ Corresponding author

\section{ABSTRACT}

Article History

Received: 28June 2021

Revised: 24 September 2021

Accepted: 20 October 2021

Published: 15 November 2021

\section{Keywords}

Spin-offs

Holding shareholder

Institutional logics

$\mathrm{R} \& \mathrm{D}$ investment

Business performance

Innovation performance.

JEL Classification: L25, L29.
Based on the panel data of 577 spin-offs of the Chinese Academy of Sciences (CAS) from 2008 to 2017 , this paper explores the moderating effect of the different types of holding shareholders on business performance and innovation performance in institute spin-offs from the perspective of institutional logics. The findings indicate that investment in research and development $(\mathrm{R} \& \mathrm{D})$ has a significant positive impact on the business performance and innovation performance of the institute spin-offs. Corporate legal representative holding shareholders positively moderate the relationship between $\mathrm{R} \& \mathrm{D}$ investment and business performance. Due to the conflict of incentive mechanism, research institute legal representative holding shareholders negatively moderate the relationship between $\mathrm{R} \& \mathrm{D}$ investment and both areas of performance. Scientist natural person holding shareholders positively moderate the relationship between $\mathrm{R} \& \mathrm{D}$ investment and both areas of performance. The research conclusions of this paper enrich the research on institute spin-offs and expand the research on the role of holding shareholders in business operation.

Contribution/Originality: The paper's primary contribution is finding the differential impact of different holding types on the performance of institute spin-offs from the perspective of institutional logic theory. This study provides theoretical guidance for the adjustment of the shareholding structure of spin-offs.

\section{INTRODUCTION}

Institute spin-offs are new enterprises established for the purpose of commercializing knowledge, technology, and research findings generated by scientific research institutes (Steffensen, Rogers, \& Speakman, 2000). Research institutes are the key components of regional and national innovation systems (Abreu \& Grinevich, 2017), and institute spin-offs are seen as potential sources of disruptive innovation (Skute, 2019). The quality of entrepreneurial activities in China have been improving in recent years, but there are still certain gaps compared with developed countries. The innovation quality of entrepreneurial activities still requires improvements, and there is only a limited number of spin-offs cultivated by scientific research institutes (O'Shea, Allen, Chevalier, \& Roche, 2005). Academic entrepreneurs face many challenges, particularly in creating and sustaining business output (Vohora, Wright, \& Lockett, 2004). The traditional non-commercial environment of research institutes leads to a lack of support for these start-ups in their initial stage and subsequent development (Lockett \& Wright, 2005). 
The gradual rise of academic entrepreneurship facilitates the rapid development of entrepreneurship research (Zhang, Qu, \& Yun, 2014). It is of great significance for scholars, industrial practitioners and policy makers to understand the important factors, mechanisms and potential influencing factors of academic entrepreneurship (Balven, Fenters, Siegel, \& Waldman, 2018; Fini, Rasmussen, Siegel, \& Wiklund, 2018). The entrepreneurial motivation of spin-offs are considered to be the result of individual characteristics, or the influence of organizational policies and structures and external environments (O'Shea et al., 2005). Some scholars explain the development of spin-offs from the perspective of knowledge overflow. They believe that technology-based spin-offs utilize the knowledge from parent organizations to re-develop their corporate strategies to gain competitive advantages (Ma \& Du, 2019; Pu \& Sun, 2013). However, it cannot explain the disparity among spin-offs. Other scholars analyzed the development of spin-offs from the perspective of resource dependence; they hold that the innovative resources of parent organizations can help the enterprises obtain scarce strategic resources and thus gain competitive advantages (Koster, 2004; Liu, 2015; Zhang \& Li, 2005). However, it's difficult to measure the source support. The explanation of corporate entrepreneurship with institutional logics has drawn the attention of an increasing number of scholars (Liu, Zhang, \& Jing, 2016), including that of venture capital (Pahnke, Katila, \& Eisenhardt, 2015). Yet there are relatively few studies on academic entrepreneurship in the context of China, especially on the development differences of institute spin-offs from the perspective of institutional logics.

First introduced by Alford \& Friedland (1985), the concept of institutional logic was used to describe the contradiction between practice and belief inherent in western society (Alford \& Friedland, 1985). Jackall defined institutional logics as a series of rules, values and judgments created by individuals in a specific environment, the function of which is to make individual behaviors and corresponding concepts standardized and predictable to a certain extent (Jackall, 1988). The core of institutional logic theory is to explain how institutions shape the heterogeneity, stability, and change within individuals and organizations through the fundamental logics behind them (Thornton \& Ocasio, 2008), and how individuals and organizations respond to the institutional environment $(\mathrm{Yu}, 2015)$. Thornton further proposed six main elements of institutional logic: market, firm, profession, family, religion, and state (Thornton, 2004). An organization often has one dominant logic and many other logics, which may be incompatible or even conflicting (Greenwood, Raynard, Kodeih, Micelotta, \& Lounsbury, 2011), but coexist in the organization for a significant length of time (Dunn \& Jones, 2010; Reay \& Hinings, 2009). As the dominant institutional logic shapes the basic assumptions and value proposition of actors, organizations tend to follow their corresponding basic cognitive and behavioral templates when carrying out their daily activities (Almandoz, 2014).

Institutional logic can more accurately explain organizational behavioral and performance differences (Pahnke et al., 2015; Thornton, Ocasio, \& Lounsbury, 2012), and make up for the insufficiency of traditional institutional theory, which places too much emphasis on the homogenization of organizational behaviors and the stability of institutional structure (Lounsbury, 2007), gradually attracting scholars' attention to the institutional logic of enterprises and senior management. When analyzing the impact of different types of holding shareholders on enterprises, scholars are gradually using the perspective of institutional logic. The difference of equity structure will lead to different dominant logics, which will exert different effects on the final economic performance and innovation performance of enterprises (Pahnke et al., 2015). Greve and Zhang believed that the ratio of state ownership and legal representative ownership of enterprises would affect their mergers \& acquisitions (M\&As). When the legal representative has a relatively high ownership ratio, the market capitalist logic will be followed, and there will be a greater possibility for mergers \& acquisitions (Greve \& Man Zhang, 2017). Through a study on the spin-offs of the CAS, we have found that the holding shareholders can be divided into three categories: corporate legal representative shareholders, research institute legal representative shareholders, and scientist natural person shareholders. In the context of China, it's believed that different interest preferences of holding shareholders lead to various institutional logics in institute spin-offs, and thus result in different actions and final business performance. Therefore, it's appropriate and feasible to conduct the analysis from the perspective of institutional logic. 
Based on the above, this paper puts forward the following research question from the perspective of institutional logic: What types of institutional logics do different holding shareholders follow and how do they influence the development of enterprises? Through an analysis on the panel data of 577 institute spin-offs of CAS from 2008 to 2017 , we have found that corporate $R \& D$ investment can effectively enhance the business performance and innovation performance of spin-offs. When the holding shareholders are enterprises, market logic will be followed, and the equity control will positively moderate the relationship between R\&D investment and business performance. When the holding shareholders are institutes, professional logic will be observed, but differences in incentive systems will affect the relationship between $\mathrm{R} \& \mathrm{D}$ investment and innovation performance. When the holding shareholders are scientists (when market logic and professional logic coexist in the enterprise), the equity control by scientists can positively moderate the business performance and innovation performance. From the perspective of institutional logics, this paper interprets two kinds of performance of institute spin-offs, provides a relatively new perspective, and expands the role of different enterprise ownership types in business operation. At the same time, the research conclusions provide references for enterprise stakeholders and policy makers.

\section{LITERATURE REVIEW AND RESEARCH HYPOTHESES}

\subsection{REDD Investment and Performance of Institute Spin-offs}

The relationship between $\mathrm{R} \& \mathrm{D}$ investment and corporate performance has been studied for a long time domestically and internationally, and a relatively perfect theoretical system and many practical results have been obtained. According to the mainstream views, both domestically and internationally, there is a significant positive correlation between R\&D investment and business performance. The research of early scholars shows that increasing R\&D investment can significantly improve the income and market value of enterprises (Sougiannis, 1994). Through a study on the biotechnology companies, William and Paul verified that the value improvement of enterprises is partially attributed to R\&D investment (William \& Paul, 1996). As the global economic perspective developed, Ettlie selected a sample of manufacturing enterprises from 20 countries and found that R\&D investment significantly increased their market share (Ettlie, 1998). The viewpoint that R\&D investment is significantly positively correlated with business performance has become the mainstream view in recent years. Through the research on enterprises of different sizes and from different industries, scholars have found that R\&D is the driving force behind scientific and technological innovation (Wu, 2019), and R\&D investment has a positive impact on corporate performance (Lee, Kwon, \& Pati, 2019; Liang \& Zhang, 2005) as it can enhance corporate values (Chen, Yuan, \& Tang, 2016; He, Li, \& Yan, 2017; Xu, 2018). Many scholars have concluded that R\&D investment can improve the business performance of enterprises by taking samples of agricultural products enterprises, industrial enterprises, high-tech enterprises on growth enterprise market, and IT enterprises (Alarcón \& Sánchez, 2013; Sun, 2015; Wu, 2015; Yan \& Lin, 2013). Based on a large number of previous research findings, we put forward the following hypothesis:

Hypothesis 1A: The RED investment of institute spin-offs has a positive impact on business performance, meaning that the higher the REDD investment, the more conducive it is to the improvement of business performance.

Recent extensive studies indicate that $\mathrm{R} \& \mathrm{D}$ investment may effectively encourage enterprises to launch $\mathrm{R} \& \mathrm{D}$ activities, and thus improve their innovation performance (Jefferson, Huamao, Xiaojing, \& Xiaoyun, 2006; Xie, Dai, \& Liu, 2013). Through an analysis of manufacturing and service enterprises, Ehie found that R\&D investment can remarkably enhance innovation performance (Ehie \& Olibe, 2010). An increase in R\&D investment enables enterprises to attract more high-caliber talents, introduce more technical equipment and establish a wider range of external innovation networks, thus creating an atmosphere that promotes the absorption, utilization and creation of new knowledge, increases innovation output and enhances competitiveness (Chi, Yu, \& Ruan, 2020; Wang \& Yu, 2020). To sum this up, we put forward the following hypothesis: 
Hypothesis 1B: The RED investment of institute spin-offs has a positive impact on innovation performance, meaning that the higher the RED investment, the more conducive it is to the improvement of innovation performance.

\subsection{The Institutional Logics of Different Holding Shareholders and Moderating Effect}

In the context of China, there are two main institutional logics in institute spin-offs, namely market logic and professional logic. Under the institutional arrangement of the same share with the same rights, the shareholding ratio determines the decision-making power. High shareholding entities tend to control their decision-making power through their own shareholding advantages to realize their own interests (Ma \& Du, 2019). When the holding shareholders of the enterprises are different, the dominant logics that the enterprises follow are also different. There are three main forms of equity control in institute spin-offs, namely enterprise equity control, institute equity control and scientist equity control. In institute spin-offs featuring enterprise equity control and institute equity control, market logic and professional logic will be followed respectively; in institute spin-offs featuring scientist equity control, these two logics will coexist.

\subsubsection{The Moderating Effect of Corporate Legal Representative Holding Shareholders}

When enterprises serve as holding shareholders, the spin-offs mainly follow market logic, and focus on performance, profit, efficiency and competition (Thomann, Lieberherr, \& Ingold, 2016). Business methods are adopted to maximize the rate of return on social welfare to ensure the survival and normal operation of the organizations (Ahmadsimab \& Chowdhury, 2021; Liu et al., 2016; Pache \& Santos, 2013). Especially in the start-up stage, when spin-offs face the challenge of survival, obtaining profits to ensure their survival plays a more important role, and corporate shareholders pay more attention to current profit and profitability (Greenwood, Díaz, $\mathrm{Li}$, \& Lorente, 2010), i.e., spin-offs are dominated by market logic. Under the guidance of market logic, if the goal of profit maximization or market share maximization cannot be effectively guaranteed, shareholders will use their rights to influence the board of directors and indirectly intervene in the appointment and removal of managers (Zhao, 2021). The research and development activities of enterprises will thus be more conducive to the improvement of economic performance, which may reduce innovation output. In summary, this paper believes that when the institute spin-offs are controlled by the corporate legal representatives, the higher the R\&D investment and the more significant the facilitating effect on their economic performance. Based on this, the following hypothesis is proposed:

Hypothesis 2: The corporate legal representative holding shareholders can positively moderate the relationship between $R \mho^{D} D$ investment and the business performance of institute spin-offs.

\subsubsection{The Moderating Effect of Research Institute Legal Representative Holding Shareholders}

When research institutes serve as the holding shareholders, the spin-offs follow the dominant professional logic and focus on acquiring new knowledge through research and innovation activities in pursuit of scientific value (Bstieler, Hemmert, \& Barczak, 2015; Dunn \& Jones, 2010). Enterprises with strong professional logic will actively participate in industrial exchanges and focus on technical specialization and product innovation in the professional fields, which can help with the acquisition of professional talent resources and the formation of a virtuous circle (Dunn \& Jones, 2010). They will also be more concerned with long-term corporate development and working toward playing a leading role in the industry. Scholars hold different views on the issue of research institutes holding spin-offs. According to Di Berardino's research on the spin-offs of Italian scientific research organizations, the CEO holding two positions and the proportion of the parent organization's researchers on the board of directors have no effect on business performance (Di Berardino, 2016). By analyzing the samples of spin-offs from non-listed universities in China, Zhang found that the divested capital structure with the parent universities serving a majority shareholder was not conducive to the growth of business performance. As revealed by the research of Yuan, there is 
a "U-shaped" relationship between the shareholding ratio of parent universities and the innovation performance of spin-offs (Yuan, Li, \& Tian, 2013).

In this paper, it is argued that at the beginning of the establishment, if the spin-off is mainly controlled by the research institute, the shareholder will follow their own organizational imprint and bring the professional logic that they have been following into the initial operation and management of the enterprise, such as the pursuit of innovation and the generation of new knowledge (D'Este \& Llopis, 2016). Relying on the superior disciplines and technological strength of the parent institutes, the spin-offs boast better technical resources and thus have stronger innovation ability and innovation performance (Xie, Zou, \& Qi, 2018; Zhang \& Bai, 2019). At the same time, the research of Perkmann shows that when the professional logic of researchers cannot be met in business operation, they will constantly adjust the internal code of conduct to meet their basic research needs, such as engaging in innovative activities and publishing papers (Perkmann, McKelvey, \& Phillips, 2019).

The rich knowledge resources of parent institutes and the research needs of researchers will enhance the promoting effect of R\&D investment on the innovation performance of spin-offs. Therefore, this paper holds that when the research institutes acting as the holding shareholders of the spin-offs, the relationship between R\&D investment and innovation performance will be significantly moderated. Based on this, the following hypothesis is proposed:

Hypothesis 3: The research institute legal representative holding shareholders can positively moderate the relationship between RED investment and the innovation performance of institute spin-offs.

\subsubsection{The Moderating Effect of Scientist Natural Person Holding Shareholders}

When there are multiple logics in an organization, even though these logics may be incompatible or even conflicting, they will coexist in the organization to jointly guide corporate behaviors, thus affecting performance. For instance, commercial logic and public interest logic coexist in non-profit organizations (Ahmadsimab \& Chowdhury, 2021); academic logic coordinates with commercial logic in university industrial research and development centers (Perkmann et al., 2019); there may be multiple institutional logics in enterprises. When Vickers et al. studied social enterprises providing public services, they found that government logic, market logic and civil society logic coexisted in these mixed organizations (Liu, Li-na, \& Meng, 2020).

Some enterprises among the spin-offs are mainly controlled by scientists. As the largest shareholder, a natural person has actual control of the enterprise and corporate interests will be "bound" by personal interests (Lu, Dan, Chen, Tseng, \& Chou, 2021). Business performance represents short-term benefits, while innovation performance determines whether the enterprise can achieve sustained long-term performance. Even from the perspective of personal interests, shareholders will invest more energy and time (Liu et al., 2020) to maximize the balance between short- and long-term interests.

Therefore, the scientist holding shareholders have a higher motivation to participate in, control, and adjust business operation by obtaining effective business information and their own social relations (Pahnke et al., 2015). In this way, investment can be encouraged to produce greater returns and the relationship between $\mathrm{R} \& \mathrm{D}$ investment and business performance can be adjusted.

Since the inventors themselves are the holding shareholders of institute spin-offs, corporate behaviors will be guided by professional logic. In R\&D investment, the spin-offs are more inclined to engage in innovation activities (Ma \& Chen, 2020).

Hypothesis 4a: The scientist natural person holding shareholders can positively moderate the relationship between RED investment and business performance of institute spin-offs.

Hypothesis 4b: The scientist natural person holding shareholders can positively moderate the relationship between $R \Xi^{2} D$ investment and innovation performance of institute spin-offs. 


\section{RESEARCH METHODS}

\subsection{Sample Selection and Data Description}

Since the end of the last century, the CAS and its affiliated institutes have initiated and set up a number of hightech spin-offs. Several hundred spin-offs have become important carriers of technology transfer and industrialization of scientific and technological achievements of various units of the CAS, including famous enterprises, such as Lenovo Group and Hanvon Technology. In this paper, a total of 2,821 panel data entries of 577 enterprises were constructed based on the samples of spin-offs founded by the CAS and its subordinated research institutes. The data of some newly established spin-offs haven't been included. The data were collected from the annual survey conducted by Guoke Holding Group from 2008 to 2017. After processing on the observed data with outliers and data standardization, we obtained 1950 effective samples to form the balanced panel data.

\subsection{Variable Measurement and Research Methods \\ 3.2.1. Dependent Variables}

1) Business Performance. Operating income is an important indicator to measure the operating conditions and market share ability of an enterprise and to predict its business development trend. It's also an important index to evaluate the growth status and development ability of an enterprise. Therefore, the current operating income is used to measure the business performance of enterprises in this paper.

2) Innovation Performance. At present, the measurement indexes of innovation performance in innovation management are mostly analyzed through the number of patents, the number of new products, R\&D investment, and labor productivity. In this paper, the number of patents granted in the current year is used to measure the innovation performance of an enterprise. Patent authorization is an effective indicator that reflects the innovation performance of an enterprise, which is objective, accessible and measurable (Yu, 2021).

\subsubsection{Independent Variables}

In this paper, the total annual $\mathrm{R} \& \mathrm{D}$ investment amount is used to measure the $\mathrm{R} \& \mathrm{D}$ investment of an enterprise. $\mathrm{R} \& \mathrm{D}$ investment is concerned with both tangible and intangible elements (Wei, Wang, \& Xu, 2019). However, it is difficult to objectively measure intangible elements such as creativity and information of R\&D personnel. Hence, it is more comprehensive to measure $R \& D$ investment by the total amount of $R \& D$ investment in the form of capital (Chi et al., 2020).

\subsubsection{Moderated Variables}

The dummy variables are set as per the types of holding shareholders. For spin-offs controlled by scientists, scientists $_{i t}=1$; for spin-offs not controlled by scientists, scientists ${ }_{i t}=0$. For spin-offs controlled by enterprises, enterprises $_{i t}=1$; for spin-offs not controlled by enterprises, enterprises ${ }_{i t}=0$. For spin-offs controlled by research institutes, research institutes ${ }_{i t}=1$; for spin-offs not controlled by research institutes, research institutes ${ }_{i t}=0$.

\subsubsection{Control Variables}

Based on previous studies, this study controls some other factors that may affect business performance and innovation performance, including enterprise age, corporate assets, high-tech industry, investment abroad and export right. The high-tech industry, investment abroad and export right variables are dummy variables set according to whether it is a high-tech industry, whether it engages in investment abroad and whether it has export right. In order to control the time effect caused by the time change, this paper introduces the time dummy variable into the model as the control variable to improve the robustness of the model. The variable setting is shown in Table 1 below. 
Table 1. Variable Setting

\begin{tabular}{l|l|l}
\hline Variable Type & Variable Name & Measurement Index \\
\hline Dependent Variables & Business Performance & Operating Income \\
\hline Independent Variables & Innovation Performance & Rumber of Patents Awarded \\
\hline \multirow{2}{*}{ Moderated Variables } & Equity Control by Enterprises & $\begin{array}{l}\text { Whether the holding shareholder is an } \\
\text { enterprise }\end{array}$ \\
\hline \multirow{5}{*}{ Control Variables } & $\begin{array}{l}\text { Equity Control by Research } \\
\text { Institutes }\end{array}$ & $\begin{array}{l}\text { Whether the holding shareholder is a research } \\
\text { institute }\end{array}$ \\
\cline { 2 - 3 } & Equity Control by Scientists & Whether the holding shareholder is a scientist \\
\hline \multirow{5}{*}{} & Enterprise Age & Enterprise age \\
\cline { 2 - 3 } & Corporate Assets & Gross value of assets \\
\cline { 2 - 3 } & Oigh-tech Industry & Whether it's in the high-tech industry \\
\cline { 2 - 3 } & Export Right & Whether it has overseas investment \\
\cline { 2 - 3 } & Year & Whether it has export right \\
\hline
\end{tabular}

Note: All continuous variables are standardized in the regression. The Hausman test was used to select the model in this paper, and the results showed that the pvalue corresponding to the Hausman statistics should be selected to establish the random effects model.

\section{EMPIRICAL RESULTS AND ANALYSIS}

4.1. Descriptive Statistical Analysis

Before the regression, the corresponding descriptive statistical analysis on the samples was first conducted to learn about the basic numerical characteristics of each variable. According to the results of the analysis (see Table 2), the data processing results are relatively reasonable.

Table 2. Descriptive statistical analysis.

\begin{tabular}{l|c|c|c|c}
\hline Variable & Mean Value & Standard Deviation & Minimum Value & Maximum Value \\
\hline Business Performance & -0.08 & 0.80 & -0.28 & 17.06 \\
\hline Innovation Performance & -0.09 & 0.71 & -0.28 & 11.27 \\
\hline R\&D Investment & -0.03 & 1.05 & -0.27 & -1.79 \\
\hline Enterprise Age & -0.08 & 0.99 & -0.31 & 2.27 \\
\hline Corporate Assets & -0.09 & 0.81 & 0.00 & 16.00 \\
\hline High-tech Industry & 0.43 & 0.50 & 0.00 & 1.00 \\
\hline Overseas Investment & 0.03 & 0.18 & 0.00 & 1.00 \\
\hline Export Right & 0.25 & 0.43 & & 1.00 \\
\hline
\end{tabular}

Note: $\mathrm{n}=1950$

*All data have been standardized, so the mean value may be negative.

The correlation analysis of the variables is shown in Table 3. From the correlation coefficients of the variables, there is no highly significant correlation between the independent variables.

Table 3. Correlation Test.

\begin{tabular}{|c|c|c|c|c|c|c|c|c|}
\hline & $(1)$ & $(2)$ & (3) & $(4)$ & (5) & (6) & $(7)$ & $(8)$ \\
\hline (1) Business Performance & 1 & & & & & & & \\
\hline (2) Innovation Performance & $0.51^{* * * *}$ & 1 & & & & & & \\
\hline (3) R\&D Investment & $0.80^{* * * *}$ & $0.49^{* * * *}$ & 1 & & & & & \\
\hline (4) Enterprise Age & $0.16^{* * * *}$ & $0.14^{\text {****** }}$ & $0.16^{\text {***** }}$ & 1 & & & & \\
\hline (5) Corporate Assets & $0.86^{* * * *}$ & $0.54^{\text {****** }}$ & $0.36^{\text {***** }}$ & $0.15^{\text {****** }}$ & 1 & & & \\
\hline (6) High-tech Industry & $0.21^{\text {**** }}$ & $0.2 \mathrm{O}^{* * * *}$ & $0.23^{* * *}$ & $0.33^{* * * *}$ & $0.2 \mathrm{O}^{* * *}$ & 1 & & \\
\hline (7) Overseas Investment & -0.01 & 0.02 & -0.01 & 0.00 & 0.01 & $0.08^{* * *}$ & 1 & \\
\hline (8) Export Right & $0.21^{* * * *}$ & $0.17^{\text {****** }}$ & $0.26^{* * * *}$ & $0.13^{\text {***** }}$ & $0.24^{* * * *}$ & $0.30^{* * * *}$ & $0.09^{* * * *}$ & 1 \\
\hline
\end{tabular}

\subsection{Analysis of Regression Results}

The empirical regression results of the model are shown in Table 4 and Table 5. 
Table 4. The impact of R\&D investment on business performance-the moderating of holding shareholders.

\begin{tabular}{|c|c|c|c|c|c|c|c|c|}
\hline & $(1)$ & $(2)$ & (3) & $(4)$ & $(5)$ & $(6)$ & $(7)$ & $(8)$ \\
\hline \multirow[t]{2}{*}{ R\&D Investment } & & $0.17^{* * * *}$ & $0.17^{\text {***** }}$ & $0.17^{* * * *}$ & $0.17^{* * * *}$ & $0.17^{* * * *}$ & $0.17^{* * * *}$ & $0.18^{* * * *}$ \\
\hline & & $(16.66)$ & $(16.69)$ & $(16.42)$ & $(16.66)$ & $(16.68)$ & $(16.65)$ & $(18.50)$ \\
\hline \multirow[t]{2}{*}{ Equity Control by Scientists } & & & 0.039 & 0.041 & & & & \\
\hline & & & $(1.53)$ & $(1.62)$ & & & & \\
\hline \multirow[t]{2}{*}{$\begin{array}{l}\text { R\&D Investment*Equity Control } \\
\text { by Scientists }\end{array}$} & & & & $0.017^{* *}$ & & & & \\
\hline & & & & $(2.47)$ & & & & \\
\hline \multirow[t]{2}{*}{ Equity Control by Enterprises } & & & & & -0.02 & -0.02 & & \\
\hline & & & & & $(-0.96)$ & $(-0.80)$ & & \\
\hline \multirow[t]{2}{*}{$\begin{array}{l}\text { R\&D Investment*Equity Control } \\
\text { by Enterprises }\end{array}$} & & & & & & $0.19^{* * * *}$ & & \\
\hline & & & & & & $(13.98)$ & & \\
\hline \multirow[t]{2}{*}{$\begin{array}{l}\text { Equity Control by Research } \\
\text { Institutes }\end{array}$} & & & & & & & -0.006 & -0.03 \\
\hline & & & & & & & $(-0.28)$ & $(-1.44)$ \\
\hline \multirow[t]{2}{*}{$\begin{array}{l}\text { R\&D Investment*Equity Control } \\
\text { by Research Institutes }\end{array}$} & & & & & & & & $-0.15^{* * * *}$ \\
\hline & & & & & & & & $(-18.21)$ \\
\hline \multirow[t]{2}{*}{ Enterprise Age } & $0.03^{* *}$ & $0.03^{* *}$ & $0.03^{* *}$ & $0.03^{* *}$ & $0.03^{* *}$ & $0.03^{* *}$ & $0.03^{* *}$ & $0.03^{* *}$ \\
\hline & $(2.18)$ & $(2.33)$ & $(2.28)$ & $(2.31)$ & $(2.25)$ & $(2.25)$ & $(2.31)$ & $(2.42)$ \\
\hline \multirow[t]{2}{*}{ Corporate Assets } & $0.80^{* * * *}$ & $0.60^{\text {**** }}$ & $0.62^{\text {***** }}$ & $0.61^{\text {***** }}$ & $0.62^{\text {***** }}$ & $0.74^{* * * *}$ & $0.62^{\text {**** }}$ & $0.73^{\text {***** }}$ \\
\hline & $(74.16)$ & $(41.70)$ & $(41.69)$ & $(39.97)$ & $(41.66)$ & $(44.88)$ & $(41.69)$ & $(48.73)$ \\
\hline \multirow[t]{2}{*}{ High-tech Industry } & -0.004 & -0.01 & -0.01 & -0.01 & -0.01 & -0.02 & -0.01 & -0.02 \\
\hline & $(-0.19)$ & $(-0.62)$ & $(-0.56)$ & $(-0.53)$ & $(-0.58)$ & $(-1.09)$ & $(-0.61)$ & $(-1.00)$ \\
\hline \multirow[t]{2}{*}{ Overseas Investment } & 0.02 & 0.02 & 0.02 & 0.02 & 0.02 & 0.03 & 0.02 & 0.02 \\
\hline & $(0.25)$ & $(0.28)$ & $(0.32)$ & $(0.27)$ & $(0.36)$ & $(0.66)$ & $(0.29)$ & $(0.37)$ \\
\hline \multirow[t]{2}{*}{ Export Right } & $0.07^{* *}$ & $0.05^{* *}$ & $0.05^{* *}$ & $0.05^{* * *}$ & $0.05^{* *}$ & 0.03 & $0.05^{* *}$ & 0.03 \\
\hline & $(2.53)$ & $(2.03)$ & $(2.13)$ & $(2.19)$ & $(2.17)$ & $(1.36)$ & $(2.05)$ & $(1.28)$ \\
\hline \multirow[t]{2}{*}{ Cons } & 0.01 & 0.01 & 0.01 & -0.01 & 0.02 & 0.02 & 0.01 & 0.02 \\
\hline & $(0.24)$ & $(0.41)$ & $(0.03)$ & $(-0.09)$ & $(0.51)$ & $(0.87)$ & $(0.31)$ & $(0.82)$ \\
\hline$N$ & 1950 & 1950 & 1950 & 1950 & 1950 & 1950 & 1950 & 1950 \\
\hline $\mathrm{R}^{2}$ & 0.73 & 0.78 & 0.78 & 0.78 & 0.78 & 0.80 & 0.78 & 0.82 \\
\hline Year Dummy Variable & YES & YES & YES & YES & YES & YES & YES & YES \\
\hline
\end{tabular}

$\mathrm{p}<0.1,{ }^{* *} \mathrm{p}<0.05,{ }^{* * *} \mathrm{p}<0.01$.

As can be seen from the regression results in Table 4, R\&D investment has a significant positive impact on the business performance of spin-offs, which verifies Hypothesis 1A. Equity control by scientists and enterprises positively moderates the positive effect of $\mathrm{R} \& \mathrm{D}$ investment on the business performance of spin-offs, which verifies Hypothesis 2 and Hypothesis 4a. Equity control by research institutes will negatively moderate the positive effect of R\&D investment on the business performance of spin-offs.

The models in Table 5 show the moderating effect of the types of holding shareholders on the relationship between R\&D investment and innovation performance. As can be seen from the regression results in Table 5 , R\&D investment has a significant positive impact on the innovation performance of spin-offs, thus verifying Hypothesis 1B. Equity control by scientists will optimistically moderate the positive effect of R\&D investment on the innovation performance of spin-offs, which verifies Hypothesis 4b. Equity control by enterprises will negatively moderate the positive effect of $R \& D$ investment on the innovation performance of spin-offs. We believe that the reason is that, in these spin-offs, the owners of core technologies in research institutes have relatively little decisionmaking power, and the corporate legal representatives tend to focus resources on improving the commercialization of technologies rather than on the further innovation of technologies when making corporate decisions. Hence, the $\mathrm{R} \& \mathrm{D}$ investment in such spin-offs can exert a less positive impact on innovation performance than in spin-offs of other types of legal representatives. As revealed in the regression results in Table 5, equity control by research 
institutes negatively moderate the positive effect of R\&D investment on the innovation performance of spin-offs, which is consistent with the findings of Su, Lei, \& Ji-Gang (2014).

Table 5. The impact of R\&D investment on innovation performance - the moderating of holding shareholders.

\begin{tabular}{|c|c|c|c|c|c|c|c|c|}
\hline & (1) & $(2)$ & (3) & $(4)$ & $(5)$ & (6) & $(7)$ & $(8)$ \\
\hline \multirow[t]{2}{*}{ R\&D Investment } & & $0.11^{* * * *}$ & $0.11^{* * * *}$ & $0.09^{* * * *}$ & $0.11^{* * * *}$ & $0.29^{* * * *}$ & $0.11^{* * * *}$ & $0.11^{* * * *}$ \\
\hline & & $(5.34)$ & $(5.34)$ & $(4.57)$ & $(5.34)$ & $(7.65)$ & $(5.34)$ & $(5.41)$ \\
\hline \multirow[t]{2}{*}{ Equity Control by Scientists } & & & 0.01 & 0.02 & & & & \\
\hline & & & (0.09) & $(0.39)$ & & & & \\
\hline \multirow[t]{2}{*}{$\begin{array}{l}\text { R\&D Investment*Equity } \\
\text { Control by Scientists }\end{array}$} & & & & $0.13^{* * * *}$ & & & & \\
\hline & & & & $(9.57)$ & & & & \\
\hline \multirow[t]{2}{*}{ Equity Control by Enterprises } & & & & & 0.01 & 0.01 & & \\
\hline & & & & & $(0.27)$ & (0.13) & & \\
\hline \multirow[t]{2}{*}{$\begin{array}{l}\text { R\&D Investment*Equity } \\
\text { Control by Enterprises }\end{array}$} & & & & & & $-0.16^{* * * *}$ & & \\
\hline & & & & & & $(-5.61)$ & & \\
\hline \multirow[t]{2}{*}{$\begin{array}{l}\text { Equity Control by Research } \\
\text { Institutes }\end{array}$} & & & & & & & -0.03 & -0.04 \\
\hline & & & & & & & $(-0.67)$ & $(-0.82)$ \\
\hline \multirow[t]{2}{*}{$\begin{array}{l}\text { R\&D Investment*Equity } \\
\text { Control by Research Institutes }\end{array}$} & & & & & & & & $-0.04^{* *}$ \\
\hline & & & & & & & & $(-2.21)$ \\
\hline \multirow[t]{2}{*}{ Enterprise Age } & 0.03 & 0.03 & 0.03 & 0.03 & 0.03 & 0.03 & 0.03 & 0.03 \\
\hline & $(1.30)$ & $(1.29)$ & $(1.27)$ & $(1.38)$ & $(1.28)$ & $(1.32)$ & $(1.30)$ & $(1.29)$ \\
\hline \multirow{2}{*}{ Corporate Assets } & $0.49^{* * * * *}$ & $0.38^{* * * *}$ & $0.38^{* * * *}$ & $0.31^{* * * * *}$ & $0.38^{* * * *}$ & $0.28^{* * * *}$ & $0.38^{* * * *}$ & $0.41^{* * * *}$ \\
\hline & $(24.09)$ & $(12.66)$ & $(12.65)$ & $(10.28)$ & $(12.66)$ & $(8.14)$ & $(12.67)$ & $(12.50)$ \\
\hline \multirow[t]{2}{*}{ High-tech Industry } & $0.07^{*}$ & 0.06 & 0.06 & 0.06 & 0.06 & $0.06^{*}$ & 0.06 & 0.06 \\
\hline & $(1.72)$ & $(1.52)$ & $(1.53)$ & $(1.60)$ & $(1.52)$ & $(1.67)$ & $(1.53)$ & $(1.50)$ \\
\hline \multirow[t]{2}{*}{ Overseas Investment } & 0.01 & 0.02 & 0.02 & 0.01 & 0.02 & 0.01 & 0.02 & 0.02 \\
\hline & $(0.12)$ & $(0.15)$ & $(0.17)$ & (0.03) & $(0.16)$ & $(0.08)$ & $(0.14)$ & $(0.14)$ \\
\hline \multirow[t]{2}{*}{ Export Right } & 0.03 & 0.02 & 0.02 & 0.04 & 0.02 & 0.04 & 0.02 & 0.01 \\
\hline & $(0.59)$ & $(0.40)$ & $(0.44)$ & $(0.76)$ & $(0.41)$ & $(0.82)$ & $(0.39)$ & $(0.27)$ \\
\hline \multirow[t]{2}{*}{ _cons } & $-0.12^{* *}$ & $-0.11^{*}$ & $-0.12^{* *}$ & $-0.15^{* *}$ & $-0.12^{* *}$ & $-0.13^{* * *}$ & $-0.11^{*}$ & $-0.10^{*}$ \\
\hline & $(-2.02)$ & $(-1.76)$ & $(-2.01)$ & $(-2.49)$ & $(-2.01)$ & $(-2.13)$ & $(-1.71)$ & $(-1.65)$ \\
\hline$N$ & 1950 & 1950 & 1950 & 1950 & 1950 & 1950 & 1950 & 1950 \\
\hline $\mathrm{R}^{2}$ & 0.31 & 0.32 & 0.32 & 0.34 & 0.32 & 0.32 & 0.32 & 0.33 \\
\hline Year Dummy Variable & YES & YES & YES & YES & YES & YES & YES & YES \\
\hline
\end{tabular}

Note: The values in square brackets under the coefficient estimates in the table are T-statistics.

${ }^{*} \mathrm{p}<0.1,{ }^{* *} \mathrm{p}<0.05,{ }^{* * *} \mathrm{p}<0.01$.

In consistence with the actual situation, some institute spin-offs have declined business development, and their innovation and sustainable development have been questioned to varying degrees. There is a significant difference between the incentive mechanisms of spin-offs and research institutes. While the research institutes mainly generate papers as research findings, the institute spin-offs primarily produce patents as research findings and are more inclined to choose substantive innovation rather than basic research (Zhang \& Bai, 2019).

The conflict of incentive mechanisms leads to unsatisfactory innovation performance of the spin-offs (Zhou \& Ji, 2012), and R\&D investment by these spin-offs has failed to demonstrate their unique attributes and strengths in knowledge innovation and technological innovation.

Therefore, spin-offs controlled by research institutes should pay attention to the evaluation and incentive mechanisms of researchers in the parent research organizations who hold dual positions, encourage researchers to apply for patents and commercialize their research findings, promote the knowledge transfer of the parent research organizations to the spin-offs, and improve their innovation performance. 


\subsection{Robustness Test}

The following robustness tests are carried out in this paper: (1) The proxy variable of business performance, operating income, is replaced with total corporate profit as the explained variable. The regression results of this robustness test are shown in Table 6; (2) The proxy variable of innovation performance, the number of patents awarded, are replaced with the total number of inventions and patents as the explained variable. The regression results of this robustness test are shown in Table 7 . The above new explained variables are used for the robust test regression analysis, and the regression results are basically consistent with the conclusions in Table 4 and Table 5 , indicating that the results are robust.

Table 6. The impact of R\&D investment on total corporate profit-the moderating of holding shareholders.

\begin{tabular}{|c|c|c|c|c|c|c|c|c|}
\hline & $(1)$ & $(2)$ & (3) & $(4)$ & $(5)$ & (6) & $(7)$ & $(8)$ \\
\hline \multirow[t]{2}{*}{ R\&D Investment } & & $0.060^{* *}$ & $0.060^{* * *}$ & $0.050^{*}$ & $0.062^{* *}$ & $0.077^{*}$ & $0.062^{* *}$ & $0.069^{* * *}$ \\
\hline & & $(2.17)$ & $(2.17)$ & $(1.71)$ & $(2.23)$ & $(1.65)$ & $(2.21)$ & $(2.31)$ \\
\hline \multirow[t]{2}{*}{ Equity Control by Scientists } & & & 0.026 & 0.037 & & & & \\
\hline & & & $(0.35)$ & $(0.49)$ & & & & \\
\hline \multirow[t]{2}{*}{$\begin{array}{l}\text { R\&D Investment*Equity } \\
\text { Control by Scientists }\end{array}$} & & & & $0.085^{*}$ & & & & \\
\hline & & & & $(1.23)$ & & & & \\
\hline \multirow[t]{2}{*}{ Equity Control by Enterprises } & & & & & -0.060 & -0.062 & & \\
\hline & & & & & $(-0.95)$ & $(-0.99)$ & & \\
\hline \multirow[t]{2}{*}{$\begin{array}{l}\text { R\&D Investment*Equity } \\
\text { Control by Enterprises }\end{array}$} & & & & & & $0.022^{*}$ & & \\
\hline & & & & & & $(0.40)$ & & \\
\hline \multirow[t]{2}{*}{$\begin{array}{l}\text { Equity Control by Research } \\
\text { Institutes }\end{array}$} & & & & & & & 0.058 & 0.054 \\
\hline & & & & & & & $(0.91)$ & $(0.84)$ \\
\hline \multirow[t]{2}{*}{$\begin{array}{l}\text { R\&D Investment*Equity } \\
\text { Control by Research Institutes }\end{array}$} & & & & & & & & -0.040 \\
\hline & & & & & & & & $(-0.69)$ \\
\hline \multirow[t]{2}{*}{ Enterprise Age } & $0.067^{* *}$ & $0.071^{* *}$ & $0.071^{\text {** }}$ & $0.072^{* *}$ & $0.068^{* *}$ & $0.068^{* *}$ & $0.069^{* *}$ & $0.069^{* *}$ \\
\hline & $(1.99)$ & $(2.08)$ & $(2.06)$ & $(2.09)$ & $(1.98)$ & $(1.99)$ & $(2.01)$ & $(2.00)$ \\
\hline \multirow[t]{2}{*}{ Corporate Assets } & $0.53^{* * * *}$ & $0.512^{* * * *}$ & $0.513^{* * * *}$ & $0.512^{* * * *}$ & $0.515^{* * * *}$ & $0.516^{* * * *}$ & $0.513^{\text {****** }}$ & $0.511^{\text {***** }}$ \\
\hline & $(15.07)$ & $(13.82)$ & $(13.81)$ & $(13.81)$ & $(13.87)$ & $(13.86)$ & $(13.87)$ & $(13.76)$ \\
\hline \multirow[t]{2}{*}{ High-tech Industry } & $0.20^{* * * *}$ & $0.172^{* * * *}$ & $0.173^{* * * *}$ & $0.174^{* * * *}$ & $0.173^{\text {****** }}$ & $0.173^{* * * * *}$ & $0.172^{\text {***** }}$ & $0.173^{* * * *}$ \\
\hline & $(3.61)$ & $(3.12)$ & $(3.13)$ & $(3.15)$ & $(3.13)$ & $(3.13)$ & $(3.12)$ & $(3.13)$ \\
\hline \multirow[t]{2}{*}{ Overseas Investment } & 0.19 & 0.263 & 0.266 & 0.265 & 0.270 & 0.270 & 0.264 & 0.263 \\
\hline & $(0.90)$ & $(1.24)$ & $(1.25)$ & $(1.24)$ & $(1.27)$ & $(1.27)$ & $(1.24)$ & $(1.23)$ \\
\hline \multirow[t]{2}{*}{ Export Right } & -0.046 & -0.066 & -0.065 & -0.061 & -0.062 & -0.063 & -0.064 & -0.060 \\
\hline & $(-0.64)$ & $(-0.92)$ & $(-0.90)$ & $(-0.84)$ & $(-0.85)$ & $(-0.87)$ & $(-0.89)$ & $(-0.83)$ \\
\hline \multirow[t]{2}{*}{ _cons } & 0.0059 & 0.040 & 0.036 & 0.036 & 0.066 & 0.071 & 0.016 & 0.012 \\
\hline & $(0.07)$ & $(0.46)$ & $(0.42)$ & $(0.41)$ & $(0.73)$ & $(0.77)$ & $(0.17)$ & $(0.13)$ \\
\hline$N$ & 1943 & 1797 & 1797 & 1797 & 1797 & 1797 & 1797 & 1797 \\
\hline $\mathrm{R}^{2}$ & 0.260 & 0.258 & 0.258 & 0.257 & 0.262 & 0.262 & 0.263 & 0.262 \\
\hline Year Dummy Variable & YES & YES & YES & YES & YES & YES & YES & YES \\
\hline
\end{tabular}

Note: The values in square brackets under the coefficient estimates in the table are T-statistics.

${ }^{*} \mathrm{p}<0.1,{ }^{* *} \mathrm{p}<0.05,{ }^{* * *} \mathrm{p}<0.01$.

\section{MAIN RESEARCH CONCLUSIONS}

From the perspective of institutional logics, this paper studies the R\&D investment, business performance and innovation performance of institute spin-offs in China. The research findings indicate that R\&D investment has a significant positive impact on the business performance and innovation performance of spin-offs (Chen et al., 2016; Lee et al., 2019). Spin-offs controlled by corporate legal representative holding shareholders will follow market logic. Equity controlled by enterprises positively moderates the relationship between R\&D investment and business performance (Thomann et al., 2016), and negatively moderates the relationship between R\&D investment and innovation performance (Greenwood et al., 2010). Spin-offs controlled by research institutes will follow professional 
logic, and research institute legal representative holding shareholders will negatively moderate the relationship between R\&D investment and business performance (Di Berardino, 2016; Zhang \& Xia, 2012).

Table 7. The impact of R\&D investment on corporate inventions and patents - the moderating of holding shareholders.

\begin{tabular}{|c|c|c|c|c|c|c|c|c|}
\hline & $(1)$ & $(2)$ & $(3)$ & $(4)$ & $(5)$ & (6) & $(7)$ & $(8)$ \\
\hline \multirow[t]{2}{*}{ R\&D Investment } & & $0.208^{* * * *}$ & $0.209^{* * * *}$ & $0.168^{* * * *}$ & $0.209^{* * * *}$ & $0.242^{* * * *}$ & $0.208^{* * * *}$ & $0.243^{* * * *}$ \\
\hline & & $(8.42)$ & $(8.43)$ & $(6.63)$ & $(8.41)$ & $(5.27)$ & $(8.38)$ & $(9.26)$ \\
\hline \multirow[t]{2}{*}{$\begin{array}{l}\text { Equity Control by } \\
\text { Scientists }\end{array}$} & & & 0.051 & 0.100 & & & & \\
\hline & & & $(0.67)$ & $(1.33)$ & & & & \\
\hline \multirow[t]{2}{*}{$\begin{array}{l}\text { R\&D } \\
\text { Investment*Equity } \\
\text { Control by } \\
\text { Scientists }\end{array}$} & & & & $0.404^{* * * *}$ & & & & \\
\hline & & & & $(6.05)$ & & & & \\
\hline \multirow[t]{2}{*}{$\begin{array}{l}\text { Equity Control by } \\
\text { Enterprises }\end{array}$} & & & & & -0.009 & -0.014 & & \\
\hline & & & & & $(-0.14)$ & $(-0.23)$ & & \\
\hline \multirow[t]{2}{*}{$\begin{array}{l}\text { R\&D } \\
\text { Investment*Equity } \\
\text { Control by } \\
\text { Enterprises }\end{array}$} & & & & & & -0.045 & & \\
\hline & & & & & & $(-0.86)$ & & \\
\hline \multirow[t]{2}{*}{$\begin{array}{l}\text { Equity Control by } \\
\text { Research Institutes }\end{array}$} & & & & & & & -0.035 & -0.059 \\
\hline & & & & & & & $(-0.55)$ & $(-0.92)$ \\
\hline \multirow[t]{2}{*}{$\begin{array}{l}\text { R\&D } \\
\text { Investment*Equity } \\
\text { Control by } \\
\text { Research Institutes }\end{array}$} & & & & & & & & $-0.219^{* * * *}$ \\
\hline & & & & & & & & $(-3.98)$ \\
\hline \multirow[t]{2}{*}{ Enterprise Age } & $-0.102^{* * * *}$ & $-0.106^{* * * *}$ & $-0.107^{* * * *}$ & $-0.102^{* * * *}$ & $-0.106^{* * * *}$ & $-0.105^{* * * *}$ & $-0.104^{* * * *}$ & $-0.105^{* * * *}$ \\
\hline & $(-2.93)$ & $(-3.00)$ & $(-3.02)$ & $(-2.89)$ & $(-2.99)$ & $(-2.97)$ & $(-2.94)$ & $(-2.98) 3$ \\
\hline \multirow[t]{2}{*}{ Corporate Assets } & $0.180^{* * * * *}$ & $0.134^{* * * *}$ & $0.135^{* * * * *}$ & $0.127^{* * * *}$ & $0.134^{* * * *}$ & $0.135^{* * * * *}$ & $0.133^{* * * *}$ & $0.124^{* * * *}$ \\
\hline & $(5.52)$ & $(4.06)$ & $(4.10)$ & $(3.89)$ & $(4.06)$ & $(4.08)$ & $(4.04)$ & $(3.79)$ \\
\hline \multirow[t]{2}{*}{$\begin{array}{l}\text { High-tech } \\
\text { Industry }\end{array}$} & $0.457^{* * * *}$ & $0.418^{* * *}$ & $0.419^{* * * *}$ & $0.422^{* * * *}$ & $0.418^{* * * *}$ & $0.417^{* * * *}$ & $0.418^{* * * * *}$ & $0.422^{* * * *}$ \\
\hline & $(8.35)$ & $(7.89)$ & $(7.90)$ & (8.04) & $(7.88)$ & $(7.88)$ & $(7.89)$ & $(8.00)$ \\
\hline \multirow[t]{2}{*}{$\begin{array}{l}\text { Overseas } \\
\text { Investment }\end{array}$} & $0.388^{* *}$ & $0.464^{* *}$ & $0.471^{* * * *}$ & $0.468^{* * * *}$ & $0.467^{* *}$ & $0.467^{* *}$ & $0.462^{* *}$ & $0.459^{* *}$ \\
\hline & (2.09) & $(2.55)$ & $(2.58)$ & $(2.58)$ & $(2.56)$ & $(2.56)$ & $(2.54)$ & $(2.53)$ \\
\hline \multirow[t]{2}{*}{ Export Right } & $0.146^{* * *}$ & 0.0161 & 0.0174 & 0.0398 & 0.0166 & 0.0149 & 0.0151 & 0.0349 \\
\hline & $(2.05)$ & $(0.23)$ & $(0.25)$ & $(0.57)$ & $(0.23)$ & $(0.21)$ & $(0.21)$ & $(0.50)$ \\
\hline \multirow[t]{2}{*}{ _cons } & $-0.598^{* * * *}$ & $-0.508^{* * * *}$ & $-0.516^{* * * *}$ & $-0.515^{* * * *}$ & $-0.505^{* * * *}$ & $-0.495^{* * * *}$ & $-0.494^{* * * *}$ & $-0.513^{* * *}$ \\
\hline & $(-6.80)$ & $(-5.89)$ & $(-5.92)$ & $(-5.95)$ & $(-5.59)$ & $(-5.44)$ & $(-5.46)$ & $(-5.68)$ \\
\hline$N$ & 1916 & 1869 & 1869 & 1869 & 1869 & 1869 & 1869 & 1869 \\
\hline $\mathrm{R}^{2}$ & 0.165 & 0.210 & 0.209 & 0.221 & 0.209 & 0.209 & 0.210 & 0.211 \\
\hline $\begin{array}{l}\text { Year Dummy } \\
\text { Variable }\end{array}$ & YES & YES & YES & YES & YES & YES & YES & YES \\
\hline
\end{tabular}

Note: The values in square brackets under the coefficient estimates in the table are T-statistics.

${ }^{*} \mathrm{p}<0.1,{ }^{* *} \mathrm{p}<0.05,{ }^{* * *} \mathrm{p}<0.01$.

However, due to the conflict of incentive mechanisms between research institutes and enterprises, the equity control of research institutes has a negative moderating effect on the relationship between R\&D investment and innovation performance (Su et al., 2014). Spin-offs controlled by scientists will follow both market logic professional logic, and positively moderate the relationship between R\&D investment and the two areas of performance (Ma \& Chen, 2020; Zhang \& Su, 2008). The research conclusions of this paper enrich the research on institute spin-offs and expand the role of different types of enterprise ownership in business operation.

This study provides systematic management inspiration for the improvement of the business performance and innovation performance of China's institute spin-offs. Spin-offs should strengthen R\&D investment and attach 
importance to technological innovation and development to improve their business performance and innovation performance. From the perspective of institutional logics, spin-offs controlled by scientists can improve both their business performance and innovation performance; spin-offs controlled by enterprises should prioritize the improvement of innovation performance; and spin-offs controlled by research institutes should focus on the adjustment of incentive mechanisms for R\&D personnel and the development of market logic to comprehensively boost their corporate competitiveness.

However, there are also some shortcomings in this paper. The data sources used in this paper only cover the CAS. Although the CAS has relatively mature experience in corporate spin-offs, there are environmental differences between institute spin-offs represented by CAS spin-offs and university spin-offs. Due to the lack of a comparative analysis on institute spin-offs and university spin-offs, the applicability of research conclusions herein to university spin-offs are yet to be discussed and verified. Moreover, although mainstream empirical research methods are adopted in this paper, including the use of panel regression to quantitatively study the influencing factors of the performance of spin-offs and results, the specific mechanisms of the institutional logics of spin-offs are not fully explained, and other research methods and models need to be combined for further research.

Funding: This research was supported by the National Natural Science Foundation of China: No.71932009.

Competing Interests: The authors declare that they have no competing interests.

Acknowledgement: All authors contributed equally to the conception and design of the study.

\section{REFERENCES}

Abreu, M., \& Grinevich, V. (2017). Gender patterns in academic entrepreneurship. The Journal of Technology Transfer, 42(4), 763794. Available at: https://doi.org/10.1007/s 10961-016-9543-y.

Ahmadsimab, A., \& Chowdhury, I. (2021). Managing tensions and divergent institutional logics in firm-npo partnerships. Journal of Business Ethics, 168(3), 651-670. Available at: https://doi.org/10.1007/s 10551-019-04265-x.

Alarcón, S., \& Sánchez, M. (2013). External and internal R\&D, capital investment and business performance in the Spanish agrifood industry. Journal of Agricultural Economics, 64(3), 654-675. Available at: https://doi.org/10.1111/14779552.12015 .

Alford, R. R., \& Friedland, R. (1985). Powers of theory: Capitalism, the state, and democracy. Cambridge: Cambridge University Press. Almandoz, J. (2014). Founding teams as carriers of competing logics: When institutional forces predict banks' risk exposure. Administrative Science Quarterly, 59(3), 442-473. Available at: https://doi.org/10.1177/0001839214537810.

Balven, R., Fenters, V., Siegel, D. S., \& Waldman, D. (2018). Academic entrepreneurship: The roles of identity, motivation, championing, education, work-life balance, and organizational justice. Academy of Management Perspectives, 32(1), $21-42$. Available at: https://doi.org/10.5465/amp.2016.0127.

Bstieler, L., Hemmert, M., \& Barczak, G. (2015). Trust formation in university-industry collaborations in the US biotechnology industry: IP policies, shared governance, and champions. Journal of Product Innovation Management, 32(1), 111-121. Available at: https://doi.org/10.1111/jpim.12242.

Chen, J., Yuan, M., \& Tang, X. (2016). Can R\&D investment increase corporate value: A test based on innovation inventory. Science and Technology Management Research, 36(11), 8-14.

Chi , R., Yu, J., \& Ruan, H. (2020). A research on the impact of enterprise size and r\&d investment on innovation performance: From the perspective of credit environment and knowledge stock. East China Economic Management, 34(9), 43-54.

D’Este, P., \& Llopis, O. (2016). Beneficiary contact and innovation: The relation between contact with patients and medical innovation under different institutional logics. Research Policy, 45(8), 1512-1523. Available at: https://doi.org/10.1016/j.respol.2016.03.004.

Di Berardino, D. (2016). Corporate governance and firm performance in new technology ventures. Procedia Economics and Finance, 39, 412-421. Available at: https://doi.org/10.1016/s22 12-5671(16)30342-2. 
Dunn, M. B., \& Jones, C. (2010). Institutional logics and institutional pluralism: The contestation of care and science logics in medical education, 1967-2005. Administrative Science Quarterly, 55(1), 114-149. Available at: https://doi.org/10.2189/asqu.2010.55.1.114.

Ehie, I. C., \& Olibe, K. (2010). The effect of R\&D investment on firm value: An examination of US manufacturing and service industries. International Journal of Production Economics, 128(1), 127-135. Available at: https://doi.org/10.1016/j.ijpe.2010.06.005.

Ettlie, J. E. (1998). R\&D and global manufacturing performance. Management Science, 44(1), 1-11.

Fini, R., Rasmussen, E., Siegel, D., \& Wiklund, J. (2018). Rethinking the commercialization of public science: From entrepreneurial outcomes to societal impacts. Academy of Management Perspectives, 32(1), 4-20. Available at: https://doi.org/10.5465/amp.2017.0206.

Greenwood, R., Díaz, A. M., Li, S. X., \& Lorente, J. C. (2010). The multiplicity of institutional logics and the heterogeneity of organizational responses. Organization Science, 21(2), 521-539. Available at: https://doi.org/10.1287/orsc.1090.0453.

Greenwood, R., Raynard, M., Kodeih, F., Micelotta, E. R., \& Lounsbury, M. (2011). Institutional complexity and organizational responses. Academy of Management annals, 5(1), 317-371. Available at: https://doi.org/10.1080/19416520.2011.590299.

Greve, H. R., \& Man Zhang, C. (2017). Institutional logics and power sources: Merger and acquisition decisions. Academy of Management Journal, 60(2), 671-694. Available at: https://doi.org/10.5465/amj.2015.0698.

He, Y., Li, N., \& Yan, M. (2017). An analysis of the impact of R\&D investment on the financial performance of listed manufacturing companies: Based on the perspective of value creation. Journal of Nanchang University (Humanities and Social Sciences Edition), 48(6), 64-71.

Jackall, R. (1988). Moral mazes: The world of corporate managers. International Journal of Politics, Culture, and Society, 1(4), 598614.

Jefferson, G. H., Huamao, B., Xiaojing, G., \& Xiaoyun, Y. (2006). R\&D performance in Chinese industry. Economics of Innovation and New Technology, 15(4-5), 345-366.

Koster, S. (2004). Divestiture firms and individual start-ups. Are They Really Different. Paper presented at the The 44th ERSA Conference.

Lee, J., Kwon, H.-B., \& Pati, N. (2019). Exploring the relative impact of R\&D and operational efficiency on performance: A sequential regression-neural network approach. Expert Systems with Applications, 137, 420-431. Available at: https://doi.org/10.1016/j.eswa.2019.07.026.

Liang, L., \& Zhang, H. (2005). An empirical study on R\&D investment performance of high-tech listed companies. Journal of the Central South University (Social Sciences Edition), 11(2), 232-236.

Liu, Y. (2015). A research on resource activation, acquisition and integration of innovative university divestitures. Harbin: Harbin Institute of Technology Press.

Liu, Y., Zhang, C., \& Jing, R. (2016). Coping with multiple institutional logics: Temporal process of institutional work during the emergence of the one foundation in China. Management and Organization Review, 12(2), 387-416. Available at: https://doi.org/10.1017/mor.2015.49.

Liu, S.-S., Li-na, Q., \& Meng, Z. (2020). Executive compensation stickiness, major shareholder control and corporate value: An empirical study of 210 natural person holding companies. Commercial Research, 62(5), 140-145.

Lockett, A., \& Wright, M. (2005). Resources, capabilities, risk capital and the creation of university spin-out companies. Research Policy, 34(7), 1043-1057. Available at: https://doi.org/10.1016/j.respol.2005.05.006.

Lounsbury, M. (2007). A tale of two cities: Competing logics and practice variation in the professionalizing of mutual funds. Academy of Management Journal, 50(2), 289-307. Available at: https://doi.org/10.5465/amj.2007.24634436.

Lu, C.-C., Dan, W., Chen, X., Tseng, C.-K., \& Chou, K.-W. (2021). Evaluation of the operating performance of Taiwanese machine tool industry with the dynamic network DEA model. Enterprise Information Systems, 15(1), 87-104. Available at: https://doi.org/10.1080/17517575.2019.1709662. 
Ma, L., \& Du, B. (2019). Multiple shareholders' decision power allocation: Behavior logic and path strategy—a case study of vanke group. Management Review, 31(10), 273-289.

Ma, L., \& Chen, Z. (2020). Technology divestitures: Divestiture motivation, resource inheritance and competition and harmony relationship. Management Modernization, 4O(05), 56-59.

O'Shea, R. P., Allen, T. J., Chevalier, A., \& Roche, F. (2005). Entrepreneurial orientation, technology transfer and spinoff performance of US universities. Research Policy, 34(7), 994-1009. Available at: https://doi.org/10.1016/j.respol.2005.05.011.

Pache, A.-C., \& Santos, F. (2013). Inside the hybrid organization: Selective coupling as a response to competing institutional logics. Academy of Management Journal, 56(4), 972-1001. Available at: https://doi.org/10.5465/amj.2011.0405.

Pahnke, E. C., Katila, R., \& Eisenhardt, K. M. (2015). Who takes you to the dance? How partners' institutional logics influence innovation in young firms. Administrative Science Quarterly, 60(4), 596-633. Available at: https://doi.org/10.1177/0001839215592913.

Perkmann, M., McKelvey, M., \& Phillips, N. (2019). Protecting scientists from Gordon Gekko: How organizations use hybrid spaces to engage with multiple institutional logics. Organization Science, 30(2), 298-318. Available at: https://doi.org/10.1287/orsc.2018.1228.

$\mathrm{Pu}$, M., \& Sun, D. (2013). A study on entrepreneurs' knowledge inheritance and divestiture entrepreneurship: From the perspective of entrepreneurial elements. Science-Technology and Management, 15(05), 49-53.

Reay, T., \& Hinings, C. R. (2009). Managing the rivalry of competing institutional logics. Organization Studies, 30(6), 629-652. Available at: https://doi.org/10.1177/0170840609104803.

Skute, I. (2019). Opening the black box of academic entrepreneurship: A bibliometric analysis. Scientometrics, 120(1), $237-265$. Available at: https://doi.org/10.1007/s1 1192-019-03116-w.

Sougiannis, T. (1994). The accounting based valuation of corporate R\&D. Accounting Review, 69(1), 44-68.

Steffensen, M., Rogers, E. M., \& Speakman, K. (2000). Spin-offs from research centers at a research university. Journal of Business Venturing, 15(1), 93-111. Available at: https://doi.org/10.1016/s0883-9026(98)00006-8.

Su, J., Lei, X., \& Ji-Gang, S. (2014). Between university and society: A study on University-owned listed companies of China. Studies in Science of Science, 32(7), 1029-1051.

Sun, Y. (2015). A research on the correlation between R\&D expenditure and business performance of listed companies: Based on the data of listed companies in information technology industry. Communication of Finance and Accounting, 2015(18), 63$66+69$.

Thomann, E., Lieberherr, E., \& Ingold, K. (2016). Torn between state and market: Private policy implementation and conflicting institutional logics. Policy and Society, 35(1), 57-69. Available at: https://doi.org/10.1016/j.polsoc.2015.12.001.

Thornton, P. H. (2004). Markets from culture: Institutional logics and organizational decisions in higher education publishing. Stanford,CA: Stanford University Press.

Thornton, P. H., \& Ocasio, W. (2008). Institutional logics. In Greenwood, R. Oliver, C. ， Suddaby, R. छ Sahlin -Andersson, K. Eds. The Sage Handbook of Organizational Institutionalism. London: Sage.

Thornton, P. H., Ocasio, W., \& Lounsbury, M. (2012). The institutional logics perspective: A new approach to culture, structure and process. Oxford: Oxford University Press.

Vohora, A., Wright, M., \& Lockett, A. (2004). Critical junctures in the development of university high-tech spinout companies. Research Policy, 33(1), 147-175. Available at: https://doi.org/10.1016/s0048-7333(03)00107-0.

Wang, Q., \& Yu, Y. (2020). The impact of R\&D investment on innovation performance of high-tech industries. China Collective Economy, 2020(32), 69-70.

Wei, X., Wang, H., \& Xu, H. (2019). Innovation investment, innovation environment and performance of high-tech industries. Forum on Science and Technology in China, 11, 30-37. 
William, W. M., \& Paul, M. S. (1996). Effect of R\&D expenditures and funding strategies on the market value of biotech firms. Journal of Engineering and Technology Management, 12(4), 287-299. Available at: https://doi.org/10.1016/09234748(95)00014-3.

Wu, Y. (2015). Equity control by executives, R\&D investment and corporate performance: Empirical evidence from high-tech enterprises on GEM. Communication of Finance and Accounting, 33, 41-44+129.

$\mathrm{Wu}, \mathrm{Y}$. (2019). A research on the impact of R\&D investment on corporate performance: A case study of the growth enterprise market. Market Modernization, 2019(3), 113-114.

Xie, X., Dai, Z., \& Liu, S. (2013). R\&D investment and new product innovation performance of high-tech enterprises: A comparative study based on panel data. Industrial Engineering and Management, 18(3), 92-96.

Xie, X., Zou, H., \& Qi, G. (2018). Knowledge absorptive capacity and innovation performance in high-tech companies: A multimediating analysis. Journal of Business Research, 88, 289-297. Available at: https://doi.org/10.1016/j.jbusres.2018.01.019.

$\mathrm{Xu}$, B. (2018). Winning by quality: Technological innovation and business performance. Operations Research and Management Science, 27(11), 193-199.

Yan, S., \& Lin, L. (2013). R\&D investment, human capital and corporate performance growth. Academic Forum, 36(05), $127-131$.

Yu, K. H. (2015). Institutional pluralism, organizations, and actors: A review. Sociology Compass, 9(6), 464-476. Available at: https://doi.org/10.1111/soc4.12269.

Yu, M. (2021). Supply chain innovation, R\&D organizational structure and corporate innovation performance. Studies in Science of Science, 39(2), 375-384.

Yuan, C., Li, Y., \& Tian, Y. (2013). An empirical analysis of the impact of corporate governance of university divestitures on independent innovation capability: Evidence from listed university companies in China. Science of Science and Management of S.ङ T, 34(12), 147-156.

Zhang, S., \& Li, X. (2005). Corporate divestiture, resource inheritance and competitive advantage. Academic Research, 2015(04), 31-36.

Zhang, S., \& Su, X. (2008). The strategy selection and performance of start-up divestitures. RङDD Management, 1, 18-25.

Zhang, C., \& Xia, Q. (2012). An empirical analysis of the relationship between corporate governance structure and corporate performance of non-listed university divestitures in China: Based on Nationwide Samples. Technology Economics, 31(1), $1-7$.

Zhang, Y., Qu, Y., \& Yun, L. (2014). A summary of topics of management research and entrepreneurship research under the context of China. Foreign Economics \& Management, 36(1), 65-72.

Zhang, C., \& Bai, P. (2019). A research on R\&D intensity and innovation performance of listed university divestitures. Soft Science, 33(9), 128-133.

Zhao, X. (202 1). Shareholder centrism or board centrism—the definition, judgment and selection of corporate governance mode. Law Review, 39(3), 68-82.

Zhou, N., \& Ji, C. (2012). A study on the problems and development of school-run enterprises. Chinese University Science \& Technology, 2012(7), 54-55. 